\title{
As vozes da letra na fonosfera grega: um estudo sobre os cantares da Antiguidade ${ }^{1}$
}

Voices of letter in Greek phonosphere: study of chanting in Antiquity

Tiago Éric de Abreu ${ }^{2}$ UFU - Universidade Federal de Uberlândia tiagoeabreu@gmail.com 


\section{Resumo}

A historiografia da Antiguidade grega apresenta música e linguagem intimamente associadas. As fórmulas métricas pressupõem artifícios mnemônicos e indicam a preponderância da dimensão aural das performances sobre a escrita. Haveria características intrínsecas da língua grega que amoldariam as possibilidades melódicas? Ao ser colocada a questão do elo música-palavra, a seguinte rede temática será evidenciada: como se forma a ressonância melódico-textual? De que modo se dá, no canto, a convergência de elementos rítmico-melódicos, semânticos e performáticos? Ora propomos um estudo do elo canto-palavra desde os vestígios de canções gregas notadas com a escrita musical antiga. A problematização das relações entre o ritmo musical, a melodia e a métrica poética põe à mostra possíveis características das inflexões vocálicas como arquétipos específicos de performances e composições. Pela perspectiva da filosofia humanista da música (LIPPMAN, 2006), entende-se a vocalidade grega como um rito. A partir desse prisma, é possível interpretar as práticas composicionais e os vestígios de performances nas canções, considerando os valores antrópicos - mitopoéticos e catárticos - que se expressam nos gêneros lítero-musicais.

Palavras-chave: Vocalidade. Gêneros lítero-musicais. Composição aural.

\section{Abstract}

The historiography of Greek Antiquity presents music and language intimately associated. The metrical formulas presuppose mnemonic resources and suggest the correlations of aural paradigms and writing practices. Are there intrinsic aspects of Greek language that could shape melodic possibilities? The ancient conceptions about the music and poetry links are to be emphasized. How are structured the melody-text semantic resonances? How the rhythmic-melodic, semantic and performatic relations converge in chanting? The present article proposes to answer those questions by studying the singing-writing relation in the remaining Greek songs with ancient musical notation. The research of the musical rhythm, melody and poetic metrics associations reflects about vocal inflections that project specific ways of conceiving performance and composition. By the Humanistic Philosophy of Music (LIPPMAN, 2006) perspective, to understand the Greek vocality as a ritual manifestation will help us to interpret literomusical genres of Antiquity. It is thus possible to study the compositional practices and remnants of song performance, considering Greek vocality imbued with mythopoeic and cathartic meanings.

Keywords: Vocality. Musical-poetic genres. Aural composition.

O presente trabalho foi realizado com apoio da Coordenação de Aperfeiçoamento de Pessoal de Nível Superior - CAPES, processo número 1800586. 


\section{Introdução}

Aquele que propaga o canto projeta adiante sua voz (Hesíodo - "O trabalho e os dias")

Os estudos da cultura musical da Antiguidade abrangem diversos aspectos da fonosfera ${ }^{3}$ grega, e sua fonte principal de pesquisa são os textos poéticos, filosóficos e de teoria musical, escritos desde o século VIII a.C. até os primórdios da era Cristã. Logo, parte significativa do conhecimento sobre a música na Grécia advém da interpretação de textos filosóficos e literários. No século XXI surgem estudos que se dedicam a interpretar a interface música-palavra a partir do corpus de poesia lírica, épica e trágica, tradição que habitualmente era cantada e dançada por um coro.

Os tratados de teoria musical antiga, segundo Tomás (2002, p. 13), abrangem temas sobre práticas instrumentais, estilística, construção de instrumentos, notação, reunindo reflexões sobre ciência, ética, educação, metafísica, política e religião. $\mathrm{Na}$ aproximação da vocalidade grega, cotejarei as fontes historiográficas e literárias com as pesquisas recentes sobre a cultura musical da Antiguidade. À cosmovisão lítero-musical grega centrada na voz chamaremos o primado do texto nas inflexões vocais da melopeia ${ }^{4}$, tomando-a como questão de estudo.

A ideia elementar do primado do texto na canção grega pode ser interpretada a partir dos hinos e fragmentos textuais. O corpus remanescente da Antiguidade, ainda que conte poucos fragmentos de notação musical, sugere a existência de fórmulas melódicas - prática chamada "composição oral-formulaica". A primeira pergunta a ser colocada é: de que forma, na cosmovisão grega, o ritmo poético, em paralelo ao ritmo linguístico, se relaciona à memória e à transmissão oral?

Para a tarefa deste estudo, na proposta da filosofia humanista da música (LIPPMAN, 2006), mobilizam-se conhecimentos sobre performance e composição aural, articulando os prismas da experiência musical e da vocalidade (ou transmissão oral). Os sentidos que integram a fonosfera grega manifestam-se na língua, estão concretizados na literatura (poesia lírica e dramática, principalmente) e também nas reflexão teóricas, em diálogo com as práticas musicais. Ainda que consideremos haver um descompasso entre as especulações teóricas dos séculos V e IV a.C. e a música concretizada nos dramas trágicos, por exemplo, os remanescentes e vestígios literários nos ajudam a completar lacunas na investigação da musicalidade grega.

\footnotetext{
3 Por "fonosfera" compreendemos o conjunto de fenômenos gestuais e sonoros que acompanham as manifestações vocais na cultura helênica, isto é, o canto, a recitação (parasemaínesthai), a língua falada e a escrita alfabética; relações de ressonância entre os sons articulados e sua semântica global.

4 "Melopeia", neste contexto, traduz o termo grego melopoiía - "composição melódica".
} 
Os fenômenos musicais gregos podem, ainda, ser pensados em termos de uma tradução cultural (BURKE, 2005) que os torne acessíveis ao universo discursivo contemporâneo. A tradução da cultura musical grega em termos da pesquisa e do léxico musicológico permite interpretar os sentidos que se produzem na relação entre a vocalidade ${ }^{5}$ e a memória.

\section{Cosmovisões musicais da Antiguidade}

O itinerário histórico da Grécia através do tempo e sua localização geopolítica transformaram a região em zona de intercâmbios das culturas norte-africanas, do Oriente Médio e europeias. De acordo com Stiga e Kopsalidou (2012), fábulas, cerimónias religiosas, elementos linguísticos, danças tradicionais e a música das diferentes regiões do espaço helénico são testemunho desta convergência cultural. A complexa trama cultural que entrelaça os costumes das múltiplas etnias no território grego é melhor compreendida se considerarmos que, na Atenas do século $V$ a.C. - por exemplo -, medravam e conviviam práticas orais e a relativamente recente difusão da escrita alfabética.

O musicólogo lisboeta Aires Manuel R. R. Pereira (2001) efetua uma leitura dos textos do drama trágico grego considerando-os como documentos fonético-musicais e encontra elos significativos entre a língua e a música helênica, por meio da interpretação da poesia dramática ática e da paleo-organologia. Segundo o pesquisador, os textos dos tragediógrafos contêm indicações de ritmos, instrumentos, além de permitirem inferir os caracteres éticos das composições.

O estudo de Pereira contribui para a compreensão do fenômeno musical grego desde a perspectiva que reúne a teoria musical, as escrituras filosóficas e os textos poéticos para a investigação da relação entre mélos e épos, isto é, os sentidos produzidos na relação entre o campo das alturas melódicas e a palavra. Logo, o estudo das formas originárias da literatura grega oferece questões para se problematizar as vertentes da mousiké grega em termos do que hoje chamamos canto, poesia oral e literatura.

A narrativa mítica da Magna Grécia projetou a figura de Orfeu, o cantor e tangedor da lira que extasiava os seres sencientes com suas harmonias. Orfeu se tornou um arquétipo do valor hipnagógico e poético da música, e sua imagem reaparece em vários momentos da histórica musical do Ocidente, em óperas e em obras de Lizst, Offenbach, Gluck, Monteverdi, Stravinski, Berio, Philip Glass e Harry Partch.

O estudo de Ordep Serra (2015, p. 21) sobre os "Hinos Órficos" sustenta que Orfeu é símbolo da poíesis ${ }^{6}$, uma atividade que dá frutos em todas as esferas da imaginação. A imagem de Orfeu com sua lira alude à união originária entre poesia e canto, melodia e acompanhamento instrumental.

5 Sobre "transmissão oral", Cf. Paul Zumthor, La letra y la voz (1989).

$6 \quad 0$ conceito de poíesis será problematizado adiante. 
Desde os testemunhos escritos mais remotos as propriedades mágicas atribuídas à música pelos antigos gregos derivam de elementos amalgamados: a palavra e o canto, a poesia, composta em métrica, e a melodia, que convergem em ritmo e entonação. Intonação ou entonação é a gestualidade vocálica que faz perceber as alturas melódicas, tanto na recitação, no canto ou no discurso eloquente dos oradores.

Como a historiografia já há demonstrado, o musical é campo mútuo da arte dos sons e dos movimentos, da palavra e da dança. O canto associado a um texto poético, e em certas ocasiões vinculado também a movimentos coreográficos, caracterizava uma práxis multívoca chamada mousiké. Barker (2005, p. 20) afirma que a mousiké, termo de amplo escopo semântico, podia significar, além de "música", também "narrativa" e "poesia", ainda quando narrativa e poesia não fossem entoadas em canto. Note-se que a ideia evocada pelo termo "poesia", na sua atual acepção, não corresponde plenamente ao conceito grego do século $\mathrm{V}$ a.C.

\begin{abstract}
Uma explicação bastante coerente sobre a peculiaridade da música grega antiga e sua relação com a literatura nos proporciona Marcel Detienne, que assinala, em seu texto "Os mestres da verdade na Grécia arcaica" (2004), que a tradição literária no tempo antigo era, antes de tudo, tradição oral, por isso era necessário desenvolver a memória a partir do recurso rítmico da poesia. Justamente as musas - a palavra moûsa, assinala Detienne, em sua acepção não vulgar significa "palavra cantada", "palavra ritmada" - são filhas de Mnemosyné, isto é, a memória (AGUILAR, 2013, p. 72).
\end{abstract}

A observação de Aguilar assinala a relação entre ritmo e memória; a versificação métrica dos cantos épicos seria um dispositivo da mnemotécnica tradicional, veiculando histórias e narrativas cantadas ou entoadas, reverberante na forma de transmissão oral.

A função mnemônica do ritmo é enfatizada por Havelock ao referir-se à língua literária empregada nas composições:

The earlier form came into existence as an instrument for the preservation of oral speech through memorization. This memorized form was not the vernacular of casual conversation but an artificially managed language with special rules for memorization, one of which was rhythm (HAVELOCK, 1963, p. 134).

Cantar é lembrar. A relação da memória com as estruturas rítmicas das línguas é tanto mais evidente quanto mais irrefletida e implícita no próprio funcionamento linguístico e em seus elementos coesivos. Seria somente pela repetição, pela recorrência de padrões e movimentos cíclicos que o ritmo linguístico favorece a memorização? Ou existem formas musicais específicas que produzem percepções e sensações e assim impressionam sensivelmente a audição? Na reflexão sobre o alcance dos dispositivos mnemônicos na música, consideremos que o som musical produz "formas" audíveis, e que a música vocal, melodia associada a um texto, gera também imagens dos movimentos da voz. Assim, o texto se funde à melodia e é a conjunção de ambos que amplifica a força da recordação. 
A importância histórica do canto na Grécia atravessa a era arcaica e é reconhecida até no período clássico, em que se consideraria a métrica como parte constituinte da disciplina musical. Na época grega arcaica (século VIII - VI a.C.) e, portanto, da poesia épica, fala-se de um tipo oral de composição poética que se dava na performance ante um público, cantada a partir de fórmulas e cenas típicas tradicionais. A ideia de uma "literatura" como concebida no Ocidente moderno não consegue captar a amplitude semântica dessas práticas híbridas da Antiguidade.

No âmbito dessa narratividade, o mito, na Grécia, representava uma espécie de "enciclopédia"; nas diversas narrativas eram vinculados conhecimentos sobre música, história, geografia, agricultura, sobre os deuses e a guerra; as narrativas entoadas atuavam, segundo essa interpretação, como uma codificação mnemônica e discursiva em que o logos da tradição verbalizava valores culturais e éticos (MANTOVANELI, 2011, p. 20). Entoados nas vozes dos aedos, os versos da poesia épica e lírica faziam ressoar esse verbo mítico originário, transdutor de conhecimentos. Nesse contexto, os aedos evocariam a memória catalisadora de sentimentos coletivos, dentre eles o de pertença à civilização e relação com as divindades: seguiam a corrente discursiva que recontava a história passada, cantando as ações dos heróis e também dos deuses.

À parte os aedos cantarem seguindo uma tradição remota e provavelmente anônima, na ótica de Francisco Rodríguez Adrados (1981, p. 23), tinham, concomitantemente, relativa liberdade, que lhes permitia inovar: na tradição épica, segundo o helenista, não haveria distinção, especialização, entre compositor e intérprete do canto, porque não havia a noção de um "poeta". Na performance do canto estava conformado seu sentido, de modo que a ideia de uma composição anterior à performance é inconcebível nesse contexto. Segundo esse ponto de vista, cantar é (re)criar o canto.

A performance ${ }^{7}$ vocal pode ser caracterizada como ato de produção de sentidos, presentificação da memória. Nesse sentido, a "memória" cantada é a instância não somente da rememoração e da recordação, mas da perpetuação e recriação da discursividade tradicional no tempo presente das performances. Diferente de uma história lida, a narrativa cantada, desde o ponto de vista da recepção por um público, se plasma na memória de forma sensível e aperceptiva. À dinâmica semântico-sonora que envolve o circuito performático do canto - a voz e a letra (texto oral ou escrito), estruturados em gêneros lítero-musicais, no tempo presente da performance/recepção -, chamamos fonosfera.

\section{Cantores da memória}

A Ilíada", de Homero (VIII a.C.), nos apresenta a figura do "cantor", um solista da poesia lírica. Aos cantores Homero chama aiodoi (aedos) (ADRADOS, 1981, p. 22). No contexto dos aedos, o poeta recitava ou cantava sua obra, que seria extraída daquele

\footnotetext{
7 Paul Zumthor (1989, p. 19) distingue entre "tradição oral" e "transmissão oral": a primeira se situa no tempo; a segunda, no presente da realização/acontecimento. 
acervo enciclopédico oral das tradições. Por meio da interpretação da intepretação da historiografia, podemos responder à pergunta: de que formas se relacionavam a poesia oral e a escrita literomusical no período arcaico, tendo em consideração que a poesia cantada era a forma usual de difusão de várias tradições. Esta observação precisa ser considerada com base na concomitância de práticas letradas e aurais, chamada oralidade mista9.

A poesia épica apresenta vínculos com a improvisação vocal ou composição aural, feita a partir de modelos preexistentes na experiência cultural. De que forma a métrica e a rima viabilizariam a memorização de feitos históricos, narrativas míticas, mesmo após a introdução e difusão da escrita alfabética na Grécia, adaptada do alfabeto fenício?

As pesquisas historiográficas questionam a respeito da autenticidade dos nomes autorais dos aedos mais antigos - Hesíodo e Homero -, ante a ideia de que as características estilísticas e paleográficas das cópias dos manuscritos atribuídos a eles sugeririam a pertença a uma coletividade de autores. À parte Homero ser um autor ou vários, sabemos que a poesia épica possui vínculos com uma tradição arcaica de cantos de caráter narrativo mitopoético, que se funda no verbo mítico e em motivos arquetípicos populares. Ora, um compositor herda e reinventa motivos rítmico-melódicos sempre em diálogo com as tradições. "Tradição" implica uma geração transpessoal e histórica, em que há transmissão de estruturas paradigmáticas tanto de forma aural quanto escrita.

Segundo a teoria oral-formulaica, Hesíodo e Homero teriam se servido das fórmulas métricas que indicam a existência de práticas e convenções elaboradas implícitas, indícios de transmissão oral. A hipótese de esses nomes autorais representarem uma prática coletiva mais antiga do que a colocação dos poemas na forma escrita é evidenciada se considerarmos que a poesia épica está firmada nas propriedades fundamentais do ritmo poético, engendrado pela versificação métrica ${ }^{10}$.

A métrica é, pois, fundamental para o estudo da musicalidade mediterrânea, devido à sua função rítmica. Gamberini (1962, p. 13) expõe que a música vocal helênica (e também a instrumental) se baseava em um núcleo rítmico elementar que "inflamava e dava vasão ao ímpeto vital da consciência religiosa popular". A rítmica grega é representada, sob este aspecto, como elemento mobilizador de catarses simbólicas nos corpos sociais - ritos, teatro, festivais. A mousiké grega está permeada de elementos religiosos populares.

Além do ritmo métrico da poesia grega, existe um ritmo interno às imagens evocadas pelas palavras e expressões do canto ${ }^{11}$, legíveis na interpretação do poema, e que mostram possibilidades expressivas para a performance vocal. Procurarei exemplificar

\footnotetext{
9 Oralidade mista é a concomitância de práticas orais e escritas, embora predominem as primeiras (ZUMTHOR, 1989).

10 "Metro" é o arranjo das sílabas e dos pés no verso, de acordo com certas regras; aplica-se a um trecho do verso ou a um verso inteiro ou vários. Um pé, no metro, se compõe de duas ou mais sílabas. Cada sílaba pode ser longa `ou breve .

11 "Canto" aqui refere-se à poesia cantada ou entoada com inflexões vocálicas rítmicas e melódicas.
} 
esta ideia. Hesíodo, no percurso da tradição que canta ao começo e ao fim dos poemas uma reverência às Musas, antes de iniciar o canto, a elas oferece a composição "harmonizando com o som": phoné omereýsai (HESÍODO, 2013, p. 33):

Ei tu, pelas Musas comecemos, que, para Zeus pai cantando, regozijam seu grande espírito no Olimpo, dizendo o que é, o que será e o que foi antes, harmonizando com o som: incansável flui sua voz das bocas, doce; e sorri a morada do pai Zeus altissonante com a voz, tal lírio, das deusas, irradiante; e ressoa o cume do Olimpo nevoso e os deuses a veneranda raça primo glorificam no canto (vv. 26-44)

No texto, as palavras gregas umneûsai, traduzida, no contexto, por "cantando", indica a ação de "entoar hino". A palavra portuguesa "voz" traduz, nesse contexto, o grego (audé), e o verbo aeídein evoca o ato de "cantar". Na tradição grega, as musas ensinaram a Hesíodo o "belo canto" (Teogonia, v. 22). No poema, torna-se perceptível a conjunção dos elementos rítmicos e ritualísticos (invocações) que possibilitam associações com motivos rítmico-melódicos para a intonação, peculiares à língua grega literária. $A$ invocação às musas é atravessada por elementos metalinguísticos que apontam para a cenografia do canto: iniciar o canto invocando a inspiração das forças tutelares da arte tem a função de um prelúdio à narrativa cantada, uma prática que se tornou emblemática na poesia clássica ocidental.

O cantar caracteriza, segundo a nossa interpretação da cosmovisão helênica, a instância da manifestação de uma dinâmica transpessoal que se faz audível na voz. A proximidade entre culto e canto na cosmovisão grega caracteriza a convergência de formas expressivas coreográfico-ritualísticas. Alguns remanescentes da lírica helênica apresentam relações com os ritos de primavera, como, por exemplo, a parte coral da "Canção da Andorinha" estudada por Adrados'12.

Segundo o pesquisador, a tragédia, bem como a comédia ática, provém de variadas formas de canção cultual ${ }^{13}$. Um ponto de vista análogo é expresso por Aristóteles: algumas formas literárias descenderiam das adorações cantadas em coral (Poetica, 1449a10ff). O público do teatro grego encontrava no coro das tragédias diversos ritos familiares às práticas tradicionais populares, então já institucionalizados e formalizados em "modos líricos", como, por exemplo, os "péans", cantos ao deus Apolo.

Pereira (2001, p.346) escreve:

A expressão "Péan" surge integrada num diálogo lírico no qual a música tinha um lugar de destaque. O sentido da música no espetáculo dramático é definido por Aristóteles, ao integrá-la na própria essência da tragédia, isto é: "suscitar o temor e a piedade fazendo a catarse dessas emoções" (Poética, 1449 b 27). "Existem em

\footnotetext{
12 Cf. La canción Rodia de la golondrina y la cerámica de Tera, por Francisco R. Adrados, na revista em Emerita, v. 42, n. 1, 1974. Disponível em: emerita.revistas.csic.es/index.php/emerita/article/view/998.

13 Esta afirmativa é endossada pelos estudos de Francisco R. Adrados, "The agôn and the origin of tragic chorus" (1975).
} 
cada tragédia, necessariamente seis elementos, que determinam a sua natureza. São os seguintes: fábula, caracteres, dicção, reflexão, espetáculo e canto" (Poética,1450 a 8 ).

O canto é, na interpretação da Poética, de Aristóteles, componente essencial do teatro. Por canto entenda-se a intonação melódica de textos com métrica, investida de gestualidade vocálica. Até onde as fontes escritas sobre a Antiguidade nos permitem interpretar, a música e a poesia são dois dos principais recursos do teatro e dos cultos gregos, estavam presentes nos cultos às divindades. O hino em louvor a Nêmesis, por exemplo ${ }^{14}$, apresenta formas recorrentes, tais como as fórmulas doxológicas ou de louvor e exaltação, que tendem a perpetuar os atributos do deus na memória das canções, e a presentificar seu poder dinâmico na vocalização do hino.

\section{A dimensão pragmática da voz na Antiguidade}

O modo como os antigos helenos - cantando ou escrevendo nos dialetos jônio e dório - organizaram o metro de forma intrincada e vária mobiliza elementos prosódicos da língua em um discurso poético firmado sobre relações estruturantes, de alta ressonância forma-sentido. Posto que a historiografia da Antiguidade grega apresenta música e linguagem intimamente associadas, perguntamos: haveria características intrínsecas da língua grega que amoldariam as possibilidades melódicas? Essa questão leva diretamente às relações entre música vocal e gêneros literários. Considerando que, na performance do canto, convergem elementos rítmico-melódicos, semânticos e simbólicos, teceremos uma reflexão sobre a seguinte rede temática: como se estruturam as relações entre as melodias e os textos cantados? De que maneiras se encompassam, na semântica do canto, forma e sentido?

Baseado na leitura dos testemunhos remanescentes sobre a música da Antiguidade, West (1994, p.43) afirma que

As notas das canções eram atacadas de forma clara, sem deslizar de uma para outra. Isto, de acordo com Aristóxeno, é o que diferencia canto e fala: “Na conversação, evitamos manter a voz monotônica, em um tom contínuo, em uma nota única, a não ser que sejamos impelidos a isso pela emoção; mas, ao cantar, diferentemente, evitamos a alternância contínua e desmesurada entre graves e agudos, e mantemos tons específicos".

A ideia aristoxênica de "movimento da voz" introduz a espacialidade nos estudos musicais, a metáfora geométrica é tomada como termo expressivo para a fenomenologia da invenção melódica. Ora propomos um estudo do elo canto-palavra, a principiar pelos vestígios de canções gregas notadas com a escrita musical antiga. Assim, buscaremos problematizar, a princípio, o modo como se associam as quantidades ${ }^{15}$ silábicas 
no plano da palavra, o metro, no plano dos versos, e o ritmo musical, a fim de pôr à mostra possíveis características das inflexões vocálicas que reflitam formas específicas de se representar a performances e o ato de compor cantos.

A fenomenologia da palavra na Grécia indica uma relação próxima entre o nome e a coisa/ideia que ele nomeia. Segundo Lia Tomás (2012, p.79), "a letra não é, no sentido grego, simples signo fonético e notação musical, mas é igualmente número". Nesse campo de similitudes, a estudiosa interpreta que falar e contar são atividades análogas na cosmovisão grega. Nesta ideia ressoa também a noção de música como uma aritmética oculta, uma forma de se contar inconscientemente os pulsos e outras figuras temporais da música. A letra enquanto símbolo, logo também a palavra, o som entoado são, pois, representativos e significantes; tão importante quanto os sentidos produzidos é também a forma de expressá-los, o que é perceptível nos coros do drama trágico de Eurípedes, em que a escolha das palavras está associada à produção de sons miméticos, isto é, que representam foneticamente as imagens e eventos do texto, por exemplo, com aliterações, termos duplicados, assonância (recorrência rítmica de sílabas de sons análogos).

Os remanescentes da escrita musical grega (datados do século III a.C. ao II d.C.) encontrados em papiros, inscrições em pedra e manuscritos medievais estão todos no mesmo sistema de notação, o que sugere a consolidação de uma tradição. As notas do canto são simbolizadas pelas letras do alfabeto jônico, enquanto a notação instrumental, supostamente mais antiga, possui signos específicos.

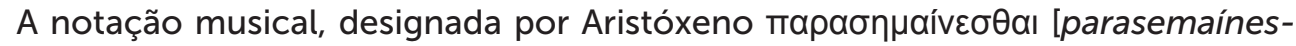
thai], indica por meio de signos sons musicais e suas durações. Mas está inserida na própria problemática do som vocálico-consonântico, na sua duração, na altura, representada pelo acento tonal, constituindo um todo entre o complexo do som e do ritmo. (Cf. Aristóxeno, Elementa harmonica, II, 39). A primeira notação musical como nos informa Isagoge (apud Gaudêncio, 347: "Os antigos usaram nomes de letras, os chamados signos musicais para uma notação de dezoito notas"). No Anonyma de Musica Scripta Bellermanniana, 68, este uso dos signos é classificado: ("a notação [instrumental] é independente do texto"). Temos as-

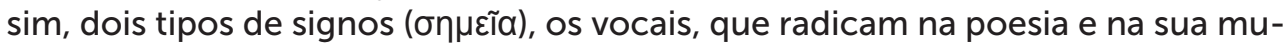
sicalidade, e os signos instrumentais que autonomizam a música instrumental. (PEREIRA, 2001, p.255)

A fonte historiográfica supracitada sugere que a crescente especialização instrumental se desenvolve no sentido de estabelecer maior independência da música instrumental em relação à vocal. A hipótese mais plausível do ponto de vista histórico, sustentada por West (1992, p.36), é que a notação instrumental seria a mais antiga.

M. L. West, que, em conjunto com Pöhlman, publicou edições críticas de manuscritos gregos com notação músico-poética, faz um estudo sobre a voz musical na Antiguidade. West (1992, p.40) sustém que as canções gregas (melopeias) eram minuciosamente articuladas com textos literários sofisticados em termos da conjunção forma-sentido. 
Seguindo a sequência cronológica dos fragmentos, observamos como a notação rítmica se desenvolve de maneira suplementar à notação das alturas melódicas. Percebe-se que as escalas enarmônicas cedem lugar às escalas cromáticas, e que estas últimas são enriquecidas, no período helenístico tardio, por acidentes semitonais, o que nos remete ao conceito moderno de cromatismo. No período romano, o gênero diatônico predomina. Por outro lado, a preleção por melismas, já presentes no século $\mathrm{V}$ a.C. (fragmento n. 3), cresce continuamente com o passar do tempo. Uma das peças mais tardias (n. 59), fragmento de um hino cristão, já prenuncia a salmodia melismática da Idade Média. Tomados em seu conjunto, os fragmentos possibilitam estabelecer a altura melódica na qual a antiga notação deve ser lida (PÖHLMAN; WEST, 2001, p.1).

Os Documents of Ancient Greek music incluem uma série de fragmentos musicais que eram desconhecidos pelos autores quando da primeira publicação feita em $1970^{16}$. Há, no entanto, significativas diferenças entre os fragmentos mais antigos (III a.C.) - que seguem a lógica da versificação métrica - e os fragmentos de hinos cristãos - compostos em prosa rítmica. Propõe-se a seguinte questão: quais seriam as diferenças, para o canto, da adoção de um sistema de composição baseado na versificação métrica e um não estrófico?

Os estudos de West e Pöhlman indicam que, nas canções gregas, as palavras seriam cantadas em entonação de forma a propiciar a nítida ressonância do logos ${ }^{17}$ textual. Consideremos a existência de um "primado do texto nas inflexões vocais da melopeia". Que relações expressivas há entre as melodias, a forma e o sentido dos textos cantados?

\section{A manuscritura ${ }^{18}$ da voz em símbolos musicais}

A notação vocal grega é estimada entre os séculos $V$ e IV a.C., uma vez que o alfabeto jônico havia sido adotado oficialmente em Atenas em 403 a.C. e estava também em uso em outras cidades (polei) gregas; além disso, a escrita musical tinha sido usada de maneira generalizada mesmo antes desse período. A forma das letras do alfabeto grego utilizado indica que a notação musical data de antes de 300 a.C. (WEST, 1992, p.42).

Os manuscritos ${ }^{19}$ estudados por Pöhlman e West (2001) não estão, no entanto, totalmente elucidados, pois apresentam lacunas e equívocos de cópia; nada obstante, neles podemos ler diversas características lítero-musicais. A personalidade de Mesomedes $^{20}$ (século II d.C.) nos chega como autor de quatorze cantos manuscritos, porém apenas dois contêm seu nome. Cinco poemas estão preservados com notação musical

\footnotetext{
16 Desde então, foram descobertos novos fragmentos musicais, publicados por Annie Bélis (2004) e Yuan (2005) - os manuscritos catalogados como "P.Oxy. 4710" e o "P.Louvre E 10534".

17 Por "logos textual" entendemos o sentido global do texto vocalizado.

18 Paul Zumthor (1989, p.116).

19 Para a relação dos manuscritos em termos de genealogia das cópias, cf. Pöhlman e West (2001, p.106-107).

20 Mesomedes teria sido, segundo a enciclopédia Suda, do século X, um compositor lírico que vivera no tempo de Adriano (113-192 d.C.).
} 
antiga em uma série de manuscritos datados do século XIII ao XVII; dentre eles há invocações à Musa, a Calíope, a Apolo e a Febo, e hinos a Helios e Nêmesis (WEST, 1992, p.106).

Imagem 1. Fragmento ${ }^{21}$ do período romano, n. 28 (século II d.C.):

\section{Hino a Nêmesis}

Transcrito a partir dos manuscritos em notação grega por Egert Pöhlman e M. L. West (2001)
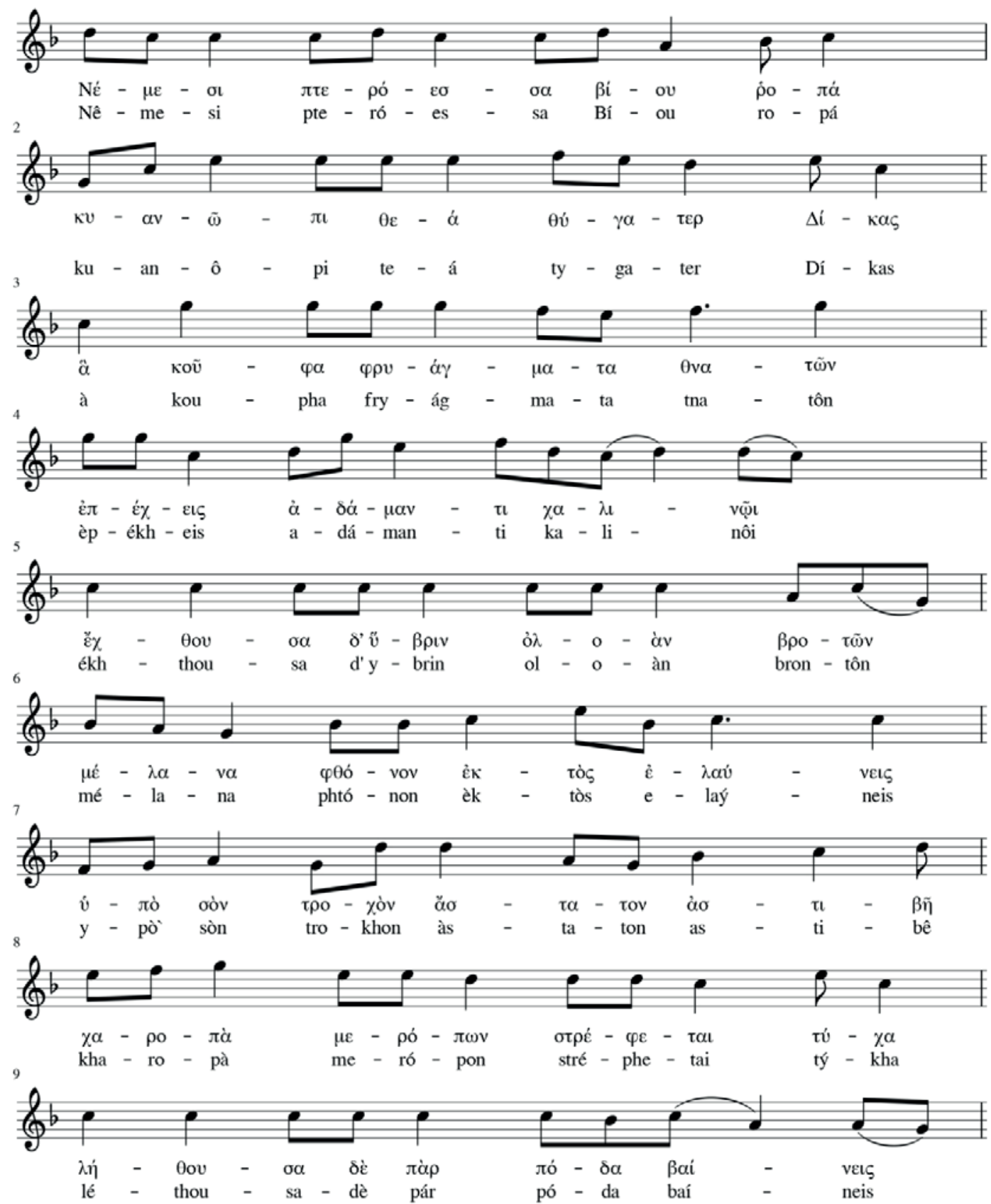
Nos hinos de Mesomedes, a maioria das linhas melódicas segue as sílabas tônicas, isto é, os momentos de maior energia dinâmica coincidem com os acentos das palavras. A possibilidade considerada nos primeiros estudos ${ }^{22}$ era de que a sílaba acentuada era entoada em um registro mais alto que as demais sílabas da palavra. A figura de três notas ascendentes é recorrente no início das linhas dos hinos de Mesomedes.

No hino supracitado a Nêmesis, na linha 4 da transcrição, a sílaba nôi - da palavra kalinôi -, uma sílaba longa, abrange duas notas melódicas:

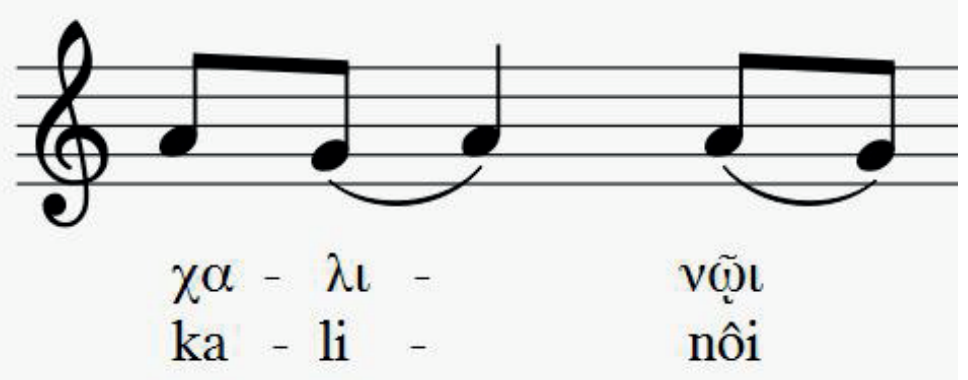

(WEST, 1992, p. 11)

Do conjunto do hino, não constitui uma regra que o acento das palavras gregas seja mantido nas melodias. As partes legíveis dos fragmentos não apresentam notáveis correspondências entre a sílaba tônica das palavras e a melodia. Apenas poucos dos fragmentos são exceções a essa ocorrência. Há, contudo, notável diferença entre os fragmentos mais antigos (século III a.C.), os Péans Délficos (séc. II a.C.) e os hinos dos primórdios da Cristandade, grafados nos manuscritos conhecidos como Oxyrhynchus: nestes últimos há acordo entre a melodia e a tônica ${ }^{23}$ das palavras; o que é a configuração mais própria às composições não estróficas, fato também reconhecido pelos gramáticos e retóricos do II século a.C. ao V d.C., de acordo com Pöhlman e West (2001, p.17). Vale observar que a tônica das palavras podia ser também deslocada por ocasião de sua posição no metro. Portanto, parece não haver, necessariamente, uma acordância entre a sílaba tônica das palavras e os tempos fortes.

A musicóloga Sophie Gibson traduz as considerações de Dionísio de Halicarnasso:

As artes da música e ritmo os modificam diminuindo ou aumentando suas durações, de maneira que elas geralmente se transformam em seu contrário: a duração não é regulada pela quantidade silábica, mas sim a quantidade da sílaba pela duração do tempo (GIBSON, 2005, p.195). 
Essa relativa independência da melodia em relação ao ritmo linguístico significa, em primeiro lugar, que os metros estruturais da tradição poética grega são convenções que não impedem, no entanto, que uma sílaba longa seja colocada em uma medida breve na versificação, o que refletiria a autonomia do canto. As fórmulas métricas pressupõem artifícios mnemônicos e indicam a preponderância da dimensão aural das performances sobre a escrita.

No corpus de hinos estudados por Pöhlman e West (2001), ainda que não constitua regra que as medidas longas e breves coincidam com as durações das notas melódicas, estatisticamente, ocorre predominância de casos em que as figuras musicais de duração (notação rítmica) correspondem às durações dos metros poéticos.

Existem, logo, em paralelo, o "ritmo linguístico", o "ritmo poético" ou "ritmo métrico" - referente às fórmulas métricas de composição estrófica - e o ritmo "musical". Consideremos, assim, duas ciências da Antiguidade: a métrica estuda os padrões formados pelo comprimento ou duração das sílabas, associadas ou não à música no sentido ocidental do termo; a rítmica (que não se distingue claramente da métrica) estuda as formas como, na intonação dos poemas, as sequências cantadas de sílabas longas e breves se subdividem e se agrupam em estruturas rítmicas (BARKER, 2005).

A visão geométrica de Aristóxeno de Trento ${ }^{24}$, teórico musical do século IV a.C., concebe que o metro está para o ritmo como a parte está para o todo. Ele classifica então ritmos segundo tipos, e assim diferencia entre o ritmo musical e os outros conceitos

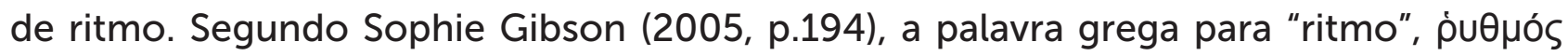
(rhythmós), em sua acepção originária, se referia a "arranjo", "condição", "estrutura", e só adquiriu um sentido musical especializado no século $V$ a.C. No contexto arcaico, rhythmós remete ao contexto mais amplo dos ritmos da natureza, dos astros, das estações etc., enfim, fenômenos que se inserem num devir cíclico.

A noção de ritmo na fonosfera grega recebe significações múltiplas. No diálogo República, Platão diferencia a poesia da prosa em função de a primeira possuir metro (métron) e a segunda não, embora atualmente nossa compreensão sobre poesia seja diferente. Métron, rhytmós e harmonia são listados como atributos distintos das canções - melopoiía composição melódica (GIBSON, 2005, p.194). A "harmonia" para os gregos engloba, portanto, todos os aspectos da música, da dança e da poesia - a métrica, o ritmo, as alturas melódicas possuem todos, analogia com a ideia de "harmonia" como conjunção, complementaridade de forças contrastantes. A ideia de "composição" ou melopoiía, em correspondência direta com a de "harmonia", representa, pois, a síntese 25 e a mistura daqueles elementos - metro, ritmo e melodia - feita por um intérprete em performance.

\footnotetext{
24 No comentário de Pseudo-Plutarco, Aristóxeno propõe que a composição (poíema) e sua performance (ermeneía) são os dois objetos do estudo crítico do teleos e do kritikos (aquele que adentrou o conhecimento aprofundado da música, para além das técnicas de composição) (ROCCONI, 2014, p.86).

25 Cf. a obra editada por Carl A. Huffman (2012), Aristoxenus of Tarentum, que reúne ensaios sobre os fragmentos de manuscritos atribuídos a Aristóxeno e citações indiretas de suas concepções musicais.
} 


\title{
5. O primado da palavra na canção grega
}

O primado da palavra na canção grega é exposto na República, de Platão:

\begin{abstract}
"O ritmo e a harmonia seguem as palavras, e não as palavras àqueles." [...]. Elas certamente devem seguir as palavras", ele disse. "E quanto ao modo de dicção, e à fala?", eu disse. "Não seguem eles e se conformam à disposição da alma?" ""Claramente." "E todos os outros elementos à dicção?" "Sim." "Boa fala, então bom acordo, e boa graça, e bom ritmo acompanham boas disposições [de ânimo emotivo], não essa fraqueza da mente à qual chamamos eufemisticamente bondade de coração, mas o verdadeiro bem e ideal disposição de caráter e mente." (STRUNK, 1959, p.7)
\end{abstract}

Os fragmentos musicais interpretados acima apontam direção diferente da ideação platônica, mostrando que, na prática, ao menos nos manuscritos estudados, que representam pequena amostra da música grega, a palavra, como estrutura linguística e poética, não é necessariamente rainha da melodia, mas as formas melódicas expressam relativa liberdade com relação aos padrões prosódicos e métricos do texto musical.

Boris Maslov (2013, p.2) coloca as considerações de Platão em outro plano hermenêutico. Segundo o autor, quando Platão recomenda que sejam a harmonia e o ritmo a se adaptarem à palavra, e não o contrário, ele entende algo diverso daquilo que ulteriores formulações análogas propuseram, nele inspiradas: não é que a harmonia e o ritmo musical, como fatos independentes, devam acordar com o sentido e o ritmo da palavra poética, mas que a "melodia", como organização rítmico-musical específica da palavra, não deve contradizer o sentido e o ethos que as palavras evocam no discurso prosaico.

$\mathrm{Na}$ interpretação de Maslov, percebemos a ideia de que o primado do texto no canto seria a preponderância do sentido das palavras e do efeito ético que se deseja que produzam na audiência. Seguindo a tradição platônica, em De musica (2.11), Aristides Quintiliano atribui afetos correspondentes aos padrões rítmicos: os elementos rítmicos veiculam caracteres, enquanto os padrões rítmicos conduzem afetos. As emoções suscitadas pela música são não apenas, em sentido literal, percepções que tomam forma na recepção da música pela audiência, mas também podem ser representadas como qualidades e formas autônomas, se admitidas como propriedades objetivas da música. Da interpretação do comentário de Platão, nos sentidos expostos supra, o domínio da palavra na música se mostraria na relação entre o sentido do texto musical e os efeitos da performance ou sua recepção senciente.

\section{Vozes nômades: a teoria oral-formulaica e a invenção permanente}

A figura do aedo, ou "bardo", cantor épico que entoava melodias de caráter lírico e também narrativo, seria um compositor. Os rapsodos, por sua vez, eram "intérpretes", mas desempenhavam, segundo Mantovaneli (2011, p.22) um papel fundamental na disseminação das obras dos aedos, pois "eram cantores ou declamadores profissionais, que percorriam diversas cidades, disseminando e, talvez, discutindo o trabalho dos Aedos com a população". 
Aedos como Hesíodo e Homero - caso tenham realmente existido -, condensaram estética e estilisticamente tradições orais mais antigas, e seus poemas firmam- se nas propriedades fundamentais da musicalidade poética: o ritmo, engendrado pela versificação métrica (métrica estrófica). A questão principal que motivou os estudos sobre as composições orais da Grécia antiga, no escopo da teoria oral-formulaica, foi discernir se os cantos eram memorizados verbatim ou se eram novamente compostos a cada ocasião em que os aedos os entoavam. Dois pesquisadores pioneiros se ativeram ao campo de estudo onde o fenômeno da tradição oral de canções épicas pudesse ser observado.

Milman Parry e Albert Lord (LORD, 1971) foram à antiga lugoslávia (atualmente, Bósnia) e gravaram as performances de cantores épicos que se apresentavam em tavernas e cafés. Os estudiosos observaram que o mesmo cantor desenvolvia os mesmos temas de maneiras distintas em ocasiões diferentes, aumentando-os, diminuindo-os ou adaptando-os, porém, o faziam de modo que fossem reconhecíveis como canções narrativas que cantam uma "mesma" história, isto é, em que temas e fórmulas recorrentes permitem identificar o "enredo" dos cantos, ou o "mito" em linguagem aristotélica.

Nas suas pesquisas, Parry e Lord (LORD, 1971) presenciaram as performances dos cantores épicos dando origem à teoria segundo a qual os bardos criam novas composições a cada vez que performam, utilizando-se de um estoque de fórmulas tradicionais de versos cantados que, em ato, são arranjadas de forma a introduzir os versos em momentos compositivos formais específicos na sequência global pré-estruturada de cada tema ou poema oral. Introduziu-se, assim, a percepção de que os cantores tivessem um mapa mnemônico do mito a ser entoado ou um esquema, atualizado, a cada performance, por repentes e escolhas. Uma permanente invenção.

O modo de relação entre canto e memória, na tradição músico-poética grega, seria a dicção "formulária": as performances ${ }^{26}$ poético-musicais eram permeadas pelas regras rítmicas da versificação. A teoria da composição "oral-formulaica" foi concebida por folcloristas no século XX empenhados em compreender as canções gregas como performances orais, no contexto de um paradigma intelectual formal-estruturalista. Os pesquisadores da teoria oral-formulaica se ocupavam em interpretar as performances músico-poéticas, seus elementos composicionais e seu impacto na audiência (FOLEY, 1988, p. IX).

A essas contribuições teóricas, acrescento a noção de rito para o estudo da vocalidade músico-poética da Magna Grécia, que engloba a importância dos valores antrópicos associados às canções (valores religiosos e catárticos, principalmente). Nada obstante, a partir dos textos da Odisseia e da llíada, por exemplo, podemos entrever, pela recorrência de versos específicos - tais como epítetos e dísticos -, elementos compositivos das performances, que teriam preexistido ao estabelecimento da tradição escrita, segundo Kirk (1962, p.60). Essas considerações não obstam, todavia, a viabilidade da concomitância de práticas escritas e orais.

26 A obra de Paul Zumthor (1983) apresenta valiosas observações sobre a voz nas performances e faz um estudo histórico-interpretativo das práticas aurais da Idade Média. 
Os estudos supracitados sugerem que as formas recorrentes nos versos dos cantos épicos seriam fórmulas que davam apoio mnemônico ao bardo e poderiam atuar como uma "assinatura", e indicar, numa performance, a autoria da composição oral pela identificação de certos padrões de individuação. Esta consideração sugere a existência de uma tradição formada de autores de composições aurais no Mediterrâneo, antes do século VIII a.C. A teoria supraesboçada oferece analogias com as tradições aurais gregas, porém não se podem generalizar as correspondências, haja vista as especificidades e condições históricas vigentes na Antiguidade. Lord (1971, p.13) considera, por analogia, que a tradição poético-musical que dera origem aos textos escritos da llíada, Odisseia, Teogonia, representada sobretudo por Homero e Hesíodo, advém de cantos compostos em performance: cantar e compor seriam atos sincrônicos.

Até onde se pôde interpretar, a ideia de composição, na Grécia, está associada à memória, ao campo ritual ${ }^{27}$-performático. A ideia de um compositor, no contexto dos aedos e rapsodos, relativiza a noção de composição e sua associação com a originalidade. O cantor é, segundo essa interpretação, um praticante da composição oral, canta temas de memória e atualiza uma tradição que se realiza nele, em seu ato performático, e inclui as condições pragmáticas de expressão das inflexões melódicas.

\section{Considerações oportunas: permanente invenção}

No período arcaico grego, os poetas-cantores eram chamados aedos porque sua atividade artística era o aídein - "cantar". Nesse contexto, os cantores se faziam acompanhar pela kíthara e/ou pelo fórmigx, ambos cordofones - imagem representada por Orfeu e sua lira. A lexicologia da aparição dos termos em torno ao campo semântico do canto na literatura sugere mudanças nas práticas culturais: o uso do léxico refletirá, em época tardia, a atribuição de autoria composicional. De acordo com o estudo La parola e la musica nell'antichitá, de Leopoldo Gamberini (1962), os usos do termo grego equivalente a "poeta" aparecem no século V a.C., no fim do período Clássico grego.

O termo poietés - "poeta - passa a designar o compositor do poema, da melodia e da dança, independentemente de ser ele também o cantor de sua composição. $O$ verbo poiéo (no sentido de "fazer", "compor" poesia) e as palavras poíesis e poíema ("poesia" e "poema") aparecem a partir da segunda metade do século V a.C. ${ }^{28}$, nos textos de Platão - tais como lon ${ }^{29}$ e nos escritos de Plutarco.

A ideia de um "poeta" como compositor surge na tradição lírica (LLEDÓ íñIGO, 1961, p.19). Tendo em conta os vestígios ônticos e históricos (literários), os testemunhos escritos nos permitem inferir o processo em que a linguagem concretiza semanticamente as práticas do compositor, do cantor e do poeta, quando transparece o reconhecimento dessas categorias no universo discursivo da Antiguidade.

\footnotetext{
27 "Ritual" refere-se à cenografia dos gêneros lítero-musicais, às ocasiões em que se cantava, seja em um banquete, um festival, um matrimônio, no teatro, para promover a catarse, em cantigas para curar, ou nos ritos de louvor a um deus, o acontecimento e ambientação em que se mobiliza a gestualidade vocálica, quaisquer sejam os atos performáticos do repertório de ações músico-linguísticas em ação. 
O estudo de Eric Havelock (1963, p.99), Preface to Plato, indica que Hesíodo marca uma transição: o ato de composição dos cantos suscita reflexões, o poeta-cantor aguça a percepção técnica e se ocupa em problematizar o propósito de sua arte, que, para os cantores tradicionais, teria sido uma prática mais inconsciente do que premeditada. (Os cantores aprendiam de forma aural desde a infância).

Havelock define o processo de compreensão da composição aural como uma busca de perceber o "canto das musas", além do mero deixar-se inspirar por elas. Se o canto épico funciona como a memória de uma cultura, diz Havelock, Hesíodo o percebeu e refletiu sobre o papel do compositor-cantor.

Na lírica ${ }^{30}$ da Magna Grécia - da qual remanescem textos e fragmentos de Píndaro, Safo, dentre outros -, coexistiam as figuras do compositor e do executante. Hesíodo veio a ser representado, portanto, como um precursor da composição de novos poemas, plasmando o arquétipo da originalidade, da individualidade que se desvincularia do ato performático de seus poemas, nos quais ressoavam as polifonias da tradição.

Nosso estudo, logo, se empenhou em pôr à mostra os vínculos profundos entre música e língua, canto, palavra e memória. A performance vocal, por esse prisma, se mostra um ato polifônico, interdiscursivo, isto é, dialoga ${ }^{31} \mathrm{com}$ um acervo "virtual" de formas-expressões arquetípicas que constituem a memória aural. Na concepção de Jardim (2000, p.186),

\begin{abstract}
A poética é um encaminhamento no sentido da Lopía [sophía]. Esta, por sua vez, significa, segundo Havelock, na compreensão homérica, o talento do bardo. $O$ saber do bardo, do aedo, era um saber produzido não pela habilidade gerada pela representação, mas para se efetuar como o que, em se realizando, se apresenta. [...] A poesia, cantada, era o mais alto grau de realização da memória.
\end{abstract}

Pode-se afirmar que as práticas lítero-musicais gregas eram capazes de ativar dispositivos mnemônicos. A relação entre palavra e canto se mostra, pois, na Grécia, em sua acepção originária, como entoação musical de um logos sonoro. Na poesia cantada se realiza uma espécie de memória espaciotemporal, ou melhor, cenográfica, de ao menos três dimensões: a mântica, a técnica e a artística. "Poética", nesse sentido, é, no dizer de Jardim (2000, p.169), a dimensão originária e essencial de realização das linguagens.

Na obra Ó Mousiké, o citado estudo da música grega por meio dos textos dos poetas tragediógrafos áticos, Pereira (2001, p.29) afirma que a melodia é naturalmente perceptível nas inflexões a que a voz é conduzida pela própria acentuação da língua grega. Segundo esse ponto de vista, haveria uma rítmica intrínseca às palavras da língua, bem como uma protomelodia inerente ao dizer.

\footnotetext{
30 A poesia lírica grega, segundo Horácio, autor do século I a.C., constituía-se de hinos de louvor endereçados a deuses e heróis, odes comemorando vitórias em jogos, poemas de amor e canções de gáudio.

31 Parece existir um "dialogismo" na música, assim como na literatura. Sobre o conceito, Cf. Bakhtin (2003).
} 
Na sua obra Problemata, [pseudo] Aristóteles considera que a música grega radica na própria musicalidade da língua, porque esta possui características melódicas que se encontram presentes na sua fonética, assente num jogo entre vogais, consoantes e ainda na métrica. Esta última é, no dizer do filósofo, a base da construção da poesia. Não é assim de estranhar que a $\mu \varepsilon \lambda$ oтoolía seja concebida ou modelada a partir do caráter cantábile da língua grega, o qual é posto em destaque por Winnington-Ingram, que vê a história da música grega em todos os seus momentos interligada com o desenvolvimento das formas literárias, especialmente da poesia. No entanto, este autor chama atenção para o fato de a melodia e a palavra se relacionarem através de um elemento de conexão - o ethos (PEREIRA, 2001, p.18).

Ao se considerar que a musicalidade mana da prosódia da língua, sugere-se que a fala, exaltada pela dinâmica afetiva, entoa contornos melódicos que a aproximam do que chamamos "canto". No campo da semântica global da performance, no plano da matéria fônica da música vocal, as línguas apresentam, dadas as características fonológicas específicas de cada idioma, atributos que amoldam seu caráter cantável, porém, não se pode ainda sustentar que haja uma relação necessária entre a materialidade fonológica de uma língua e as melodias, uma vez que a música costuma transpor algumas regras implícitas da fala e da escrita, em prol da relativa inventividade característica da ideia musical.

Briggs e Burke (2006, p.19) sustentam que a visão atual amplamente adotada pelo mundo acadêmico é a de que "a antiga cultura grega foi moldada pelo domínio da comunicação oral". A vocalidade, além do sentido de "transmissão oral", em música pode ser expressa como a inervação rítmica da palavra que, ao ser entoada, transmuda os contornos da fala em melodiares e inflexões vocálicas que produzem efeitos de sentido e efeitos éticos, segundo fórmulas melódicas reinventadas (consciente ou inconscientemente), projetando no ar repertórios de memórias.

É perceptível que, nas tradições populares, poesia, música e dança ainda perpetuem seus elos arcaicos; a música e a poesia (oral ou escrita) estão entretecidas na história da cultura musical no Ocidente. A música vocal nasce de um gesto, de um corpo-instrumento; o verbo entoado faz ecos e elos com os sons repercutidos no tempo; dialoga com outros motivos sonoros que se realizam, atualizam e se reinventam. Na música tal como a concebo em ato, a voz encena vivências anímicas através das propriedades acústicas percutidas na entonação e nos gestos semântico-sonoros realizados. 


\section{Referências}

ADRADOS, Francisco Rodríguez. La lírica grega. Madrid: Alianza editorial, 1981.

The agôn and the origin of tragic chorus. Urbana: Illinois Press, 1975.

AGUILAR, Omar Augusto Robles. Nietzsche y el origen musical de la literatura griega. La Colmena: Revista de la Universidad Autónoma del Estado de México, n. 80, p. 71-76, 2013.

ANTHON, Charles. Greek prosody and metre. New York: Harper and Brothers, 1838.

BÉLIS, Annie. Bélis Annie. Un papyrus musical inédit au Louvre. Comptes rendus des séances de l'Académie des Inscriptions et Belles-Lettres, 148区 année, n. 3, p. 1305-1329, 2004. Disponível em: http://www.persee.fr/doc/crai_0065-0536_2004_ num_148_3_22786. Acesso em: 16 maio 2019.

BRIGGS, Asa; BURKE, Peter. Uma história social da mídia. Trad. Maria Carmelita P. Dias. Rio de Janeiro: Jorge Zahar, 2006.

BURKE, Peter. O que é história cultural. Trad. Maria L. Borges. Rio de Janeiro: Jorge Zahar, 2005.

FOLEY, John Miles. The theory of oral composition. Bloomington: Indiana University Press, 1988.

GAMBERINI, Leopoldo. La parola e la música nell'antichità: confronto fra documenti musicali antichi e dei primi secoli del Medio Evo. Firenze: L.S. Olschki, 1962.

GIBSON, Sophie. Aristoxenus of Tarentum and the birth of musicology. New York: Routledge, 2005.

HAVELOCK, Eric. Preface to Plato. Harvard: Belknap Press, 1963.

HESÍODO. Os trabalhos e os dias. Trad. Luís Otávio F. Mantovaneli. São Paulo: Odysseus, 2011.

Teogonia. Trad. Christian Werner. São Paulo: Hedra, 2013.

HUFFMAN, Carl A. (Ed.). Aristoxenus of Tarentum. New Brunswik: Rutgers University, 2012. 
JARDIM, Antonio. Música: vigência do pensar poético. Rio de Janeiro: 7Letras, 2005.

KIRK, G. S. The songs of Homer. London: Cambridge University Press, 1962.

LIPPMAN, Edward. A humanistic philosophy of music. New York: NYU Press, 2006.

LLEDÓ ÍNIIGO, Emilio. El concepto 'poíesis' en la filosofía griega. Heráclito, sofistas, Platón. Madrid: Consejo superior de investigaciones científicas, Instituto Luis Vives de filosofía, 1961.

LORD, Albert. The singer of tales. New York: Atheneu, 1971.

MANTOVANELI, Luís Otávio Figueiredo. Apresentação. In: HESÍODO. Os trabalhos e os dias. Trad. Luís Otávio F. Mantovaneli. São Paulo: Odysseus, 2011.

MASLOV, Boris. The Dialect Basis of Choral Lyric and the History of Poetic Languages in Archaic Greece. Norwegian journal for Greek and Latin studies, n. 87.1, p. 1-29, 2013. Disponível em: http://dx.doi.org/10.1080/00397679.2013.822726. Acesso em: 12 jun. 2019.

PEREIRA, Aires Manuel Rodeia dos Reis. A mousiké: das origens ao drama de Eurípedes. Lisboa: Calouste Gulbenkian, 2001.

PLATÃO. Íon. Trad. Cláudio Oliveira. Belo Horizonte: Autêntica, 2011.

PÖHLMAN, Egert; WEST, Martin L. Documents of ancient Greek music. The Extant Melodies and Fragments Edited and Transcribed with Commentary. Oxford: Clarendon Press, 2001.

ROCCONI, Eleonora. Aristoxenus and musical ethos. In: HUFFMAN, Carl A. Aristoxenus of Tarentum. New Brunswik: Rutgers university, 2012. p. 65-90.

SERRA, Ordep. Hinos órficos: perfumes. São Paulo: Odysseus, 2015.

STIGA, K.; KOPSALIDOU, E. Music and traditions of Thrace (Greece): a trans-cultural teaching tool. DEDiCA - Revista de Educação e Humanidades, n. 3, p. 145-164, mar. 2012. Disponível em: http://revistaseug.ugr.es/index.php/dedica/article/view/7094. Acesso em: 11 jun. 2019.

STRUNK, Oliver (Ed.). Source readings in music history: from classical antiquity through the romantic era. New York: W. W. Norton Company, 1959. 
TOMÁS, Lia. Ouvir o logos: música e filosofia. São Paulo: Unesp, 2002.

WEST, L. On the text of Greek musical fragments. Analecta Musica. Zeitschrift für Papyrologie und Epigraphik. p. 1-54. Bonn, 1992. Disponível em: http://ifa.phil-fak.unikoeln.de/zpe.html. Acesso em: 5 maio 2019.

YUAN, J. Fragment with musical notation. The Oxyrhynchus. Oxford, 2005.

ZUMTHOR, Paul. Introduction à la poésie orale. Paris: Éditions du Seuil, 1983.

ZUMTHOR, Paul. La letra y la voz de la "literatura" medieval. Trad. Julián Presa. Madrid: Catedra, 1989. 